\title{
Role of Incongruent Product Endorsement on the Celebrity Image
}

\author{
Arpita Srivastava $^{1} \&$ Ashok Pratap Arora ${ }^{1}$ \\ ${ }^{1}$ Management Development Institute, India \\ Correspondence: Arpita Srivastava, House No. 411, Skylark Apt, Plot no. 35, Sector 6, Dwarka, New Delhi, \\ India. E-mail: fpm07arpita_s@mdi.ac.in
}

Received: August 12, 2014

Accepted: August 26, 2014

Online Published: September 25, 2014

doi:10.5539/ijbm.v9n10p170

URL: http://dx.doi.org/10.5539/ijbm.v9n10p170

\begin{abstract}
Celebrity endorsing products for promotion is a popular advertising strategy. As the cost of getting a celebrity for promotion is substantially high, selecting the right celebrity is of great concern to advertisers. Extant literature generally indicates numerous benefits from employing celebrity endorsement and has proposed quite a few mechanisms to explain the effectiveness of the celebrity endorsement. In spite of a great deal of research that has tried to theorize the celebrity endorsement process, little is known about the criteria for choosing the right celebrity to endorse a particular product. A right celebrity endorser enhances the attitude towards the advertisements and endorsed products, but an incorrect endorser may have a negative impact. Not only the consumers' attitude towards the advertisement and the endorsed product may go down, it may also impact the celebrity endorser too. The purpose of this study is to explore whether the celebrity endorser's image gets affected by the incongruence of the endorsed product. The study was carried out to examine the celebrity image dimension in the Indian context and celebrity/product mismatch effects. In the study a survey was done on the existing celebrity image scale to see its suitability in Indian context. Further the scale was used in the experiment where different level of incongruence was tested on male and female celebrity from movies and sports to examine the celebrity/ product incongruence effects. Results showed there is an effect of incongruent advertisement on the celebrities' image but not all celebrities are affected similarly. Different celebrities are treated differently by the consumers. Some celebrities actually get positively affected while some get affected negatively. The theory of cognitive dissonance has been used to explain this behavior. The interaction of the gender of the respondents with the gender of the celebrity was also found to be significant.
\end{abstract}

Keywords: celebrity, endorsements, congruence, advertisements, gender

\section{Introduction}

Celebrity endorsement is increasingly being used by marketing firms worldwide. Across all major media and advertising outlets (television, print, radio and even in outdoor billboard advertising) celebrity endorsements are commonplace (Folkes, 1984). Celebrities can endorse products that are either related or unrelated to their area or domain. Related celebrities would usually be either using that product or would be an expert on that product by virtue of being in a particular field. For example, Tiger Woods is considered a right match for Nike shoes and Frieda Pinto for L'oreal Paris cosmetics but Madonna may not be considered such a good match for a VCR (Walker, Langmeyer, \& Langmeyer, 1993).

India with a 1.1 billion population represents a large and rapidly growing market for a number of goods and services. With the burgeoning middle class in India, foreign multinationals are entering the retail sector to expand their markets. There are approximately 273 million youth (including both urban and rural) in India out of which 85 million youth are urbane (The Marketing White Book, 2007) and the purchasing power of the Indian youth is driving the growth in the retail sector (Jain, Sudha, \& Daswani, 2009). Advertising in India plays a major role in communicating a brand-327.4 billion INR was spent on advertising in 2012 — and celebrities feature in $18 \%$ to $20 \%$ of all advertisements (Biswas, Hussain, \& O’Donnell, 2009) which suggests celebrity endorsements is a key feature in Indian advertising for marketers and advertisers. Previous studies have mentioned youth are the ones who get affected the most by the celebrity endorsements (Amos, Holmes, \& Strutton, 2008) and India being a country of young consumers who get greatly influenced by celebrity endorsements, there is need to understand how consumers view these endorsements. 
In India, cricketers and actors of the celluloid world are placed on a high pedestal. Therefore getting a cricketer or an actor for brand endorsement has always been an important marketing strategy. The efficacy of this strategy lies in the fact that Indians perceive celebrity endorsements as genuinely relevant and hence it motivates them to buy a certain product. It is more effective if the endorser and the product are a natural lifestyle fit; for instance, an actress endorses a cosmetic or a sportsperson endorses footwear, or film stars endorsing beauty products (Friedman \& Friedman, 1979). As discussed earlier, the consumer gets motivated to buy an endorsed product when he sees the fit of the endorsing celebrity with the endorsed product (Kanungo \& Pang, 1973). Scholars in their work suggested if there is a "fittingness" or match between the model and the product in the commercial, the consumers will evaluate the advertised product favorably. Research also showed a fitting endorsement boosts both the credibility, believability and attractiveness of the celebrity endorser and the attitude towards the advertisement (Kamins \& Gupta, 1994; Kamins, 1990) while a non-fitting unhealthy product such as cigarette or tobacco endorsement by sport celebrity leads to negative evaluation of the celebrity endorser. But in practice the issue is not with endorsing harmful, unhealthy product which celebrities usually do not endorse but with endorsements of regular day to day products and the effect of these endorsements on the celebrities' image. Though celebrities have agencies that handle their endorsement yet not much thought is given to the type of product endorsement deals signed by a celebrity.

Two causes have been proposed in literature for the celebrity motivation for the endorsement, the product and the compensation that is paid to the celebrity. Consumers may ascribe the endorser's readiness to endorse the product either to the innate product qualities or to the compensation obtained in lieu of the endorsement. Huge sums of money involved in contracts between endorsers and companies for endorsements have also been extensively recognized. Scholars researching product failure and consumers reaction to product failures reported that when consumers do not find any visible match between the endorser and the product endorsed, they believe that monetary gains is the motivating factor for a celebrity's favorable comments towards the product and they consequently discount the effects of the endorsement of the celebrity (Folkes, 1984). Hence the attributions to economic gains were found to cause a decline in the perceived trustworthiness of the celebrity endorser whereas decrease in attribution to economic gains led to an increase in the endorsers perceived trustworthiness (Sparkman Jr., 1982). Based on the above discussion we propose to study the impact of the incongruent endorsement on the celebrity's image and try to understand this relationship.

The proposed study has significance not only for the celebrity but also for other brands that the celebrity is endorsing simultaneously. Consumers may develop a negative perception that the celebrity is doing these endorsements for the money he or she receives, rather than believing in the merits of the product. Such image shifts can be damaging to the product and promotion. Endorsements are dependent on the celebrity's image and a negative shift in image can have a negative impact on the image of the brand. Negative information or perception about the celebrity can also impact the endorsed brands. For example, the Tiger Woods scandal caused his top five sponsors (Accenture, Nike, Gillette, Electronic Arts and Gatorade) to lose 2-3 percent of their aggregate market value after the accident (Knittel \& Stango, 2010).

\section{Literature Review and Hypothesis}

\subsection{Incongruent Advertisements}

In the celebrity endorsement literature for the match-up phenomenon (Kanungo \& Pang, 1973; Misra \& Beatty, 1990; Till \& Busler, 2000) the degree of congruence is operationalized as perceived fit between the celebrity image and the product image based on the match-up factor. Different researchers have used different terms to describe spokesperson-product fit such as appropriateness (Misra \& Beatty, 1990), relevance (Miciak \& Shanklin, 1994), consistency (Walker, Langmeyer, \& Langmeyer, 1992), fittingness (Kanungo \& Pang, 1973), congruence (Kamins, 1990; Lynch \& Schuler, 1994) and belongingness (Till \& Busler, 2000). These can be divided into two categories; relevancy between an endorser -product and schema -based expectancy of the endorsement (Fleck \& Quester, 2007). The first one, relevancy of the association, is defined as the "material pertaining directly to the meaning of the theme and reflects how information contained in the stimulus contributes to or detracts from the clear identification of the themes or primary message being communicated" (Heckler \& Childers, 1992, p. 477). In the instance of celebrity endorsement, relevancy involves the extent to which the image of the celebrity endorser is relevant to that of the product, the celebrity endorses, dependent on the match-up phenomenon. The second one, expectancy, refers to the "degree to which an item or information falls into some predetermined pattern or a structure evoked by the theme" (Heckler \& Childers, 1992, p. 477). In case of celebrity endorsement, this can be explained as the degree to which consumers identify the endorsement of the particular product by the celebrity matches to their expectations based on the earlier defined product and /or celebrity schemas (Meyers-Levy, Louie, \& Curren, 1994). 
Misra and Beatty (1990) defined congruence as occurring when the relevant characteristics of the endorser are consistent with the relevant attributes of the brand (Lane, 2000) defined incongruence in the brand extension context as the degree to which a brand extension is considered unanticipated or surprising, even though she also used the phrase fit, in the sense of consistent. Combining the two definitions, incongruence can be defined as "occurring when the relevant characteristics of the endorser are not consistent with the relevant attributes of the brand". For the purpose of this study, to test the degree of incongruence between the celebrity endorsers and a product category, three levels of incongruence is used; extreme mismatch, neither match nor mismatch and extreme match. The incongruence is based on defining the products as used by males or females and whether a celebrity who is endorsing can be considered an expert on that product. This is based on the concept of stereotyping where "stereotypical gender traits are attributed to an individual based solely on one's knowledge of their gender" (Kiesler, 1988, p. 62).

\subsection{Celebrity Image}

According to Berlo et al. (1969) source "image" should be defined from the audiences' perception rather than from the source's objective characteristics. Since the "image" of the source gets influenced and influences the communication event, it is dynamic in nature. According to Kennedy (1977) an image is multidimensional, and it contains both cognitive and emotional elements while Keller (1993, p. 3), defined brand image as the "perceptions about a brand as reflected by the brand associations held in consumer memory". Adapting Keller (1993) definition, celebrity image has been defined by Seno and Lukas (2007, p. 122) "as the perceptions about an individual who enjoys public recognition as reflected by the celebrity associations held in consumer memory". For thepurpose of this study, image is defined as "the concept of someone or something that is held or projected by the public"' (Choi \& Rifon, 2007, p. 309).

The image aspect of the celebrity that transmit qualities of a good person (e.g., pleasant, sophisticated, wise, and responsible) bring about sincere and honest perceptions of the celebrity. A small number of empirical studies confirm that celebrity images in fact shifted to product images when the endorser endorsed the product, (Batra \& Homer, 2004; Langmeyer \& Walker, 1991) but much less is known about the effects of these images on customer responses to celebrity endorsements. Kiesler (1988) studied the influence that a particular product may have on consumers' perceptions of the spokesperson marketing that product and measured the spokesperson on 8 personality traits. The findings indicated that there is no or little evidence for the influence of any of the variables on consumers' perception of spokesperson for different products. Unexpectedly Kamins and Gupta (1994) found that the match-up between a celebrity endorser and the brand endorsed also enhanced the celebrity endorser's believability and attractiveness. In the event of negative product endorsement (Tobacco) by the celebrity (Till, 2001) found that the celebrity was negatively affected. Thus in case of regular products the findings have been inconsistent to the extent that studies have either found no impact or a positive impact on the celebrity endorser. In case of endorsements of negative products there has been a decline in the celebrity credibility. This leads us to an interesting gap of finding the impact of incongruent product on the celebrity endorser. The incongruent product is definitely not a negative product by itself and neither is it considered a "fitting" product for endorser. In such a situation where the consumers will not out rightly reject the endorsement because the product is not negative or accept the endorsement because of lack of fit, they may think about the reasons for endorsement. Speck, Schumann, and Thompson, (1988, p.74) mentions in case of incongruity, "The ad becomes a cognitive challenge, a puzzle, and at least for the moment a subject is motivated to examine various parts of the ad in order to find a solution. When consumers do not find any visible match between the endorser the product endorsed, they interpret that monetary gains are the motivating factor that holds for a celebrity's favourable comments towards the product they consequently discount the effects of the endorsement of the celebrity (Folkes, 1984). Hence the attributions to economic gains were found to cause a decline in the perceived credibility of the celebrity endorser (Sparkman Jr., 1982). We hypothesize celebrity image is negatively evaluated when the celebrity is paired with an incongruent product as consumers attribute this endorsement to the huge monetary benefits which the celebrity might be receiving and consequently decrease their rating of the celebrity's image as the consumer may not approve of such a behavior. Based on the above research this study proposes the following hypothesis.

$\mathbf{H}_{\mathbf{1}}$ : Celebrity image is negatively evaluated when the celebrity is paired with an incongruent product.

\subsection{Gender of the Audience}

Baker and Churchill Jr. (1977) studying the effect of physically attractive models on advertising evaluations, reported that when affective scores were considered, subjects rated an advertisement showing a model of the opposite gender higher than they rated an advertisement having a model of their own gender. However, when 
cognitive scores were taken into consideration, this finding was not supported. Similar results were reported by Langmeyer (1991), when celebrity endorsers were used in place of models. Bruce Willis and Boomer Esiasonwere considered sexier by female subjects than male subjects. Madonna and Christie Brinkley were considered sexier by male subjects than female subjects. Though Frieden, $(1984$, p. 40) found no effects of gender of endorser on consumer response but he did report that "When in doubt, use a male endorser". According to Ohanian (1991) respondent's age and gender had no significant impact on the evaluations of the celebrity's attractiveness, trustworthiness, or expertise or on the likelihood to purchase a product promoted by the celebrity yet findings by Premeaux (2005) indicated that though celebrity endorsers influence both men and women, still men were influenced to a greater degree than women. Choi (2002) mentioned in her study that females significantly viewed the celebrity endorser to be more attractive and more of an expert and showed more favorable attitude toward the brand than males.

Edwards and La Ferle (2009) studied the interaction between the gender of the celebrity endorser and the gender of the respondents and how this impacts the processing of negative information about celebrities. They reported respondent gender did significantly interact with celebrity gender regarding ratings of celebrity trustworthiness than either a male respondent/female celebrity or female respondent/male celebrity combination. Additionally some support was found for the impact of negative information which was stronger when the celebrity was of the same sex with the respondent. However, this effect was seen for only one of the dependent measures (trustworthiness). Contrary to the previous study (Klaus \& Bailey, 2008) reported that male respondents appraised the advertisement featuring the female celebrity more favourably than the advertisement featuring the male celebrity. Hence various results from this domain of research on celebrity endorsements (gender effects) have been inconclusive. Building on the previous research of Social Comparison Jealousy, between a female consumer and female model, the result of such relationship may be derogation of the comparison other (Bower, 2001). Salovey and Rodin (1984 p. 782) argue that "the defining quality of social comparison jealousy should be degrading of the comparison person" Hence based on the above discussion this study proposes the following hypothesis.

$\mathbf{H}_{2}$ : Evaluation of same (opposite) gender celebrity image in case of incongruent celebrity endorsement would be negative (positive)
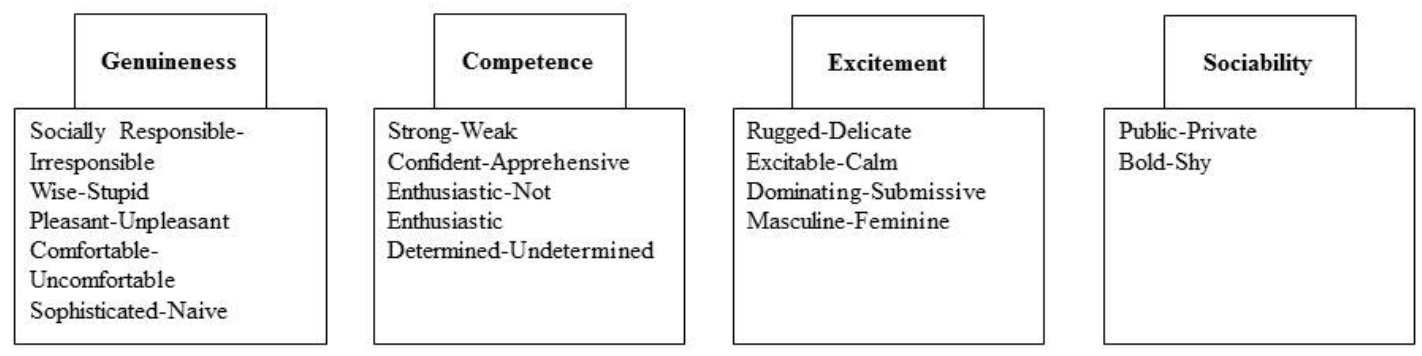

Figure 1. Celebrity image scale (Choi \& Rifon, 2007)

In the proposed model (Figure. 1) celebrity image is defined based on Choi and Rifon (2007) and the incongruent endorsements are defined based on Kiesler (1988) as not matching with the celebrity based on gender usage of the product. The model also analyze if the consumer's gender has an impact on the evaluation of the incongruent endorsements on the celebrity image. Furthermore it is suggested the effect of incongruent endorsements on shift in celebrity image can differ with gender.

\section{Materials and Methods}

To study the hypothesis that incongruence between celebrity image and product image leads to negative shift in celebrity image, we chose male and female celebrities from both movies and sports domain and tested the effect of incongruent endorsements on the celebrities' image. The following paper is organized as follows. We first provide a description of the method employed to choose a celebrity and the process of creating the stimulus material. Next, we discuss the experimental research design and collection of data and then show the effect of incongruent endorsements on celebrities.In this study, instead of focusing on products which are generally seen as negative (such as tobacco), we focus on products that are in daily use by a wide cross section of the 
population, and not evaluated as negative. Incongruence of the product endorsement was determined from the respondents, and the celebrity image was tested on a scale developed by Choi and Rifon (2007). The instrument also collected demographic information of the respondents. . Studies have shown that youth are the ones who get affected the maximum by the celebrity endorsements ( (Amos et al., 2008) and hence for this study respondents chosen were between 18-22 years.

\subsection{Sampling}

When selecting the sample of respondents, judgmental sampling was used. Since the research design was experimental, the researchers purposively selected the undergraduate colleges of New Delhi where the study can be carried out. New Delhi is the capital of India which attracts a large numbers of students from all over India for admission in various colleges. Since the study was an experimental research design with pretest and posttest data collection, a total of 189 usable response were collected having both pre and post data.

\subsection{Sampling Profile}

The sampledemographics show that $73 \%$ were females and $27 \%$ were males. The age profiles of the overall sample $(\mathrm{n}=189)$ was between $18-22$ years. The respondents were in different years of their undergraduate program. The distribution of the demographics is shown in Table 1.

Table 1. Demographic profile

\begin{tabular}{lll}
\hline & Frequency & $(\%)$ \\
\hline Age & & $53 \%$ \\
$<20$ & 100 & \\
+20 & 89 & $47 \%$ \\
Total & 189 & \\
Gender & & \\
Male & 51 & $27 \%$ \\
Female & 138 & $73 \%$ \\
Total & 189 & \\
Education & & \\
First year Undergraduate & 65 & $34 \%$ \\
Second year Undergraduate & 60 & $32 \%$ \\
Third year Undergraduate & 64 & $34 \%$ \\
Total & 189 & \\
\hline
\end{tabular}

\subsection{Data Collection}

An experimental one-group pre-test-post-test research design was developed (Malhotra, 2004) and is explained in detail here. Fictitious advertisements were selected as the stimuli, which were developed after a series of pre-tests. The study followed the procedure adopted by Roy, Gammoh, and Koh (2012). More precisely, three pre-tests were conducted sequentially on different groups of undergraduate students taking a literature course to identify the levels of the independent variables. The first pre-test was done to identify popular celebrities. The second pre-test was done to identify products that respondents have seen being endorsed by celebrities. The third pre-test was performed to select the matching and mismatching product categories with the celebrity. In summary, from movies Shahrukh Khan and Kajol were found to have the highest recall, and from sports Sachin Tendulkar and SaniaMirza were found to have highest recall in male and female category respectively. In the second pre-test five major categories emerged-Soft drinks, Snacks, Shampoos, Household electronics, and Automobiles - which had high celebrity endorsement rate. The third pre-test resulted in twelve print ads created: three for each celebrity. The three ads for each celebrity fell into three categories: match, mismatch, and neutral. While creating the print ads experts from the advertising agency were asked to suggest brand names for each product category. These brands names were fairly well known to the masses and did not have very strong brand image. 
Table 2. Celebrity—product category match

\begin{tabular}{llll}
\hline S.N & Celebrity & Congruence/Incongruence & Category \\
\hline \multirow{4}{*}{1} & \multirow{3}{*}{ Sachin Tendulkar } & Highly Match & Automobile Soft Drink \\
& & Neither Match nor Mismatch & Snacks Household Electronics \\
& & Shampoo \\
& & Highly Match & \\
& & Neither Match nor Mismatch & Soft Drink, Shampoo Automobiles, \\
2 & Shahrukh Khan & Highly Mismatch & Household Electronics \\
\hline & & Highly Match & Shampoo, Household Electronics, Snacks \\
& & Neither Match nor Mismatch & Soft drink \\
3 & Kajol & Highly Mismatch & Automobiles \\
\hline & & Highly Match & Soft drink, Shampoo \\
& & Neither Match nor Mismatch & Snacks, Automobiles \\
4 & SaniaMirza & Highly Mismatch & Household Electronics \\
\hline
\end{tabular}

A pilot test of the questionnaire was conducted before going for the main data collection. The purpose of pilot study was to find if the scale is reliable in Indian context. Fifty three male and female college students participated in the pilot study. The scale was found reliable in the Indian context and no changes were made to the scale. Based on the results we proceeded with the final stage of data collection.

In the main data collection, given that the study was experimental design with a one-group pre-test-post-test; pre-test was conducted on the celebrity image scale developed by Choi and Rifon (2007) to measure the celebrity image for four celebrities. The researchers addressed the respondents in a classroom setting where they were asked to go through the brief given on the first page of the questionnaire and the researcher also read it aloud. The brief led subjects to believe that an advertising agency is seeking their feedback on peoples' attitude towards advertising. Following this, the respondents were asked to answer a series of questions on the remaining pages of the questionnaire.

The questionnaire consisted of two parts. In the first part of the questionnaire respondents were asked evaluate the four celebrities on the celebrity image scale (Choi \& Rifon, 2007). The second part of the questionnaire had questions on demographics such as age, gender, educational level. The scale was administered on 250 respondents.

After a gap of two weeks a post-test was conducted on the same respondents to administer the stimulus material (12 print ads created) and record their responses. Following the procedure adopted by Keller, Heckler and Houston (1998) the respondents were given 12 advertisements to view, 3 for each celebrity. Three ads per celebrity were created to avoid biased response and to simulate a real life situation where a celebrity is simultaneously endorsing many products, some of them might be highly congruent, some being neither congruent nor incongruent and some incongruent. The print ads were collected back from the respondents after five minutes and same celebrity image scale (Choi \& Rifon, 2007) that was administered in the pretest was administered again to measure the celebrity image of the four celebrities. In the post-test, only 200 respondents out of 250 respondents could be contacted. Out of the 250 pre-test and 200 post-test responses only 189 respondents were found to have filled both pre- and post- questionnaires, and were neither patterned nor incomplete. These 189 responses were paired.

The celebrity image scale, presented in Figure 2, (Choi \& Rifon, 2007) used in evaluating the four celebrities had 4 constructs; Genuineness, Competence, Excitement and Sociability. Genuineness had 5 items, Competence and Excitement had 4 items, and Sociability had 2 items only. All items used semantic differential scales with a value of one associated with the more positive word and a value of five associated with the more negative word. 


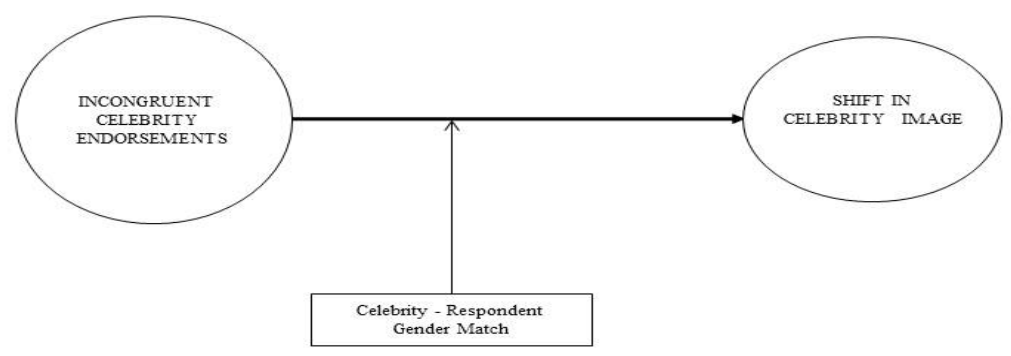

Figure 2. Proposed model

\subsection{Reliability Analysis}

Cronbach's alpha coefficient was calculated to test the reliability of the celebrity image scale, for the four constructs namely Genuineness, Competence, Excitement and Sociability for each celebrity. The Cronbach's alpha coefficient was more than 0.6 for all the four constructs, which most of the scholars agree as acceptable (Malhotra \& Grover, 1998; Narasimhan \&Jayaram, 1998). The reliability was tested for all the four celebrities and Cronbach's alpha coefficient was found to be above 0.6. Table 3 shows the result of reliability analysis.

\subsection{Manipulation Check}

To determine whether the congruent and incongruent product for a given celebrity condition was perceived in the proper way, subjects were asked (on a scale of "1 Extreme fit" to "5 Extreme misfit") to rate for each celebrity-product combination for perceived fit between the endorsed product and the celebrity. The results of the manipulation check indicated that $100 \%$ of subjects believed that perceived fit between the endorsed product and the celebrity was significantly higher for the product- celebrity match condition relative to the product-celebrity mismatch condition.

\section{Results}

\subsection{Impact on Incongruent Endorsements on Celebrity Image}

Table 4 summarizes the difference in the pretest and post test score for each celebrity on each of the four constructs of the celebrity image scale. Results of the paired sample t-test revealed that the negative shift in the celebrity image was not found to be significant while the positive shift in celebrity image was found significant for Shahrukh Khan (for Genuineness Sig. 2-tailed: 0.007), Kajol (for Genuineness Sig. 2-tailed: 0.073 and Excitement Sig. 2-tailed: 0.020) and Sachin Tendulkar (for Excitement Sig. 2-tailed: 0.015). The negative shift was found only in case of Shahrukh Khan who was rated negatively on Competence and Sania Mirza who was rated negatively on Genuineness and Competence but none of them were found to be significant. Based on the above finding $\mathrm{H}_{1}$ was rejected.

Table 3. Reliability scores of the celebrity image scale

\begin{tabular}{lllll}
\hline $\begin{array}{l}\text { Celebrity } \\
\text { Image Constructs }\end{array}$ & Shahrukh Khan & Kajol & Sachin Tendulkar & SaniaMirza \\
\hline Genuineness & 0.84 & 0.853 & 0.894 & 0.898 \\
Competence & 0.862 & 0.837 & 0.938 & 0.719 \\
Excitement & 0.774 & 0.741 & 0.657 & 0.672 \\
Sociability & 0.766 & 0.742 & 0.81 & 0.745 \\
\hline
\end{tabular}


Table 4. Paired sample T-Test for four celebrities from both male and female respondents combined

\begin{tabular}{lllll}
\hline Celebrity & Pair & Variable & Mean Difference & Sig. (2-tailed) \\
\hline Shahrukh Khan & Pair 1 & Genuineness (pre-post) & 0.12037 & $0.007^{* * *}$ \\
Shahrukh Khan & Pair 2 & Competence (pre-post) & -0.0516 & 0.297 \\
Shahrukh Khan & Pair 3 & Excitement (pre-post) & 0.04762 & 0.432 \\
Shahrukh Khan & Pair 4 & Sociability (pre-post) & 0.03 & 0.574 \\
Sachin Tendulkar & Pair 1 & Genuineness (pre-post) & 0.06296 & 0.183 \\
Sachin Tendulkar & Pair 2 & Competence (pre-post) & 0.0291 & 0.561 \\
Sachin Tendulkar & Pair 3 & Excitement (pre-post) & 0.16228 & $0.015^{* * *}$ \\
Sachin Tendulkar & Pair 4 & Sociability (pre-post) & 0.06349 & 0.355 \\
Kajol & Pair 1 & Genuineness (pre-post) & 0.0861 & $0.073^{*}$ \\
Kajol & Pair 2 & Competence (pre-post) & 0.02358 & 0.666 \\
Kajol & Pair 3 & Excitement (pre-post) & 0.14572 & $0.020^{* *}$ \\
Kajol & Pair 4 & Sociability (pre-post) & 0.08824 & 0.201 \\
SaniaMirza & Pair 1 & Genuineness (pre-post) & -0.0273 & 0.647 \\
SaniaMirza & Pair 2 & Competence (pre-post) & -0.0562 & 0.398 \\
SaniaMirza & Pair 3 & Excitement (pre-post) & 0.06422 & 0.319 \\
SaniaMirza & Pair 4 & Sociability (pre-post) & 0.04856 & 0.514 \\
\hline
\end{tabular}

Note. ***: 0.01 Significant; **: 0.05 Significant;: 0.10 Significant.

In this low Genuineness score means higher Genuineness as the scale varies from 1-5 and 5 being least Genuine. The same applies to all the other image constructs.

Table 5. Paired sample T-Test for Shahrukh khan for only female respondents

\begin{tabular}{rllll}
\hline Pair & Variable & Mean Difference & Sig. (2-tailed) \\
\hline Pair 1 & Genuineness (pre-post) & .16277 & $.002^{* * *}$ \\
Pair 2 & Competence (pre-post) & -.01460 & .815 \\
& Pair 3 & Excitement (pre-post) & .13869 & $.044^{* *}$ \\
& Pair 4 & Sociability (pre-post) & .03226 & .588 \\
\cline { 2 - 4 } Note. ${ }^{* * *}: 0.01$ Significant; **: 0.05 Significant. & &
\end{tabular}

In this low Genuineness score means higher Genuineness as the scale varies from 1-5 and 5 being least Genuine. The same applies to all the other image constructs.

Table 6. Paired sample T-Test for Shahrukh khan for only male respondents.

\begin{tabular}{llll}
\hline Pair & Variable & Mean Difference & Sig. (2-tailed) \\
\hline Pair 1 & Genuineness (pre-post) & .00865 & .916 \\
Pair 2 & Competence (pre-post) & -.14904 & $.043^{* *}$ \\
Pair 3 & Excitement (pre-post) & -.19231 & .119 \\
Pair 4 & Sociability (pre-post) & .02404 & .835 \\
\hline
\end{tabular}

Note. **: 0.05 Significant.

In this low Genuineness score means higher Genuineness as the scale varies from 1-5 and 5 being least Genuine. The same applies to all the other image constructs. 
Table 7. Paired sample T-Test for Sachintendulkar for only female respondents

\begin{tabular}{llll}
\hline Pair & Variable & Mean Difference & Sig. (2-tailed) \\
\hline Pair 1 & Genuineness (pre-post) & .07044 & .194 \\
Pair 2 & Competence (pre-post) & .03832 & .522 \\
Pair 3 & Excitement (pre-post) & .18007 & $.016^{* * *}$ \\
Pair 4 & Sociability (pre-post) & .12226 & .152 \\
\hline
\end{tabular}

Note. ***: 0.01 Significant.

In this low Genuineness score means higher Genuineness as the scale varies from 1-5 and 5 being least Genuine. The same applies to all the other image constructs.

Table 8. Paired sample T-Test for Sachintendulkar for only male respondents

\begin{tabular}{lll}
\hline Pair Variable & \multicolumn{2}{c}{ Mean Difference Sig. (2-tailed) } \\
\hline Pair 1 Genuineness (pre-post) .04327 & .654 \\
Pair 2 Competence (pre-post) .00481 & .958 \\
Pair 3 Excitement (pre-post) & .11538 & .420 \\
Pair 4 Sociability (pre-post) & -.09135 & .400 \\
\hline
\end{tabular}

In this low Genuineness score means higher Genuineness as the scale varies from 1-5 and 5 being least Genuine. The same applies to all the other image constructs.

Table 9. Paired sample T-Test for Kajol for only female respondents

\begin{tabular}{llll}
\hline Pair & Variable & Mean Difference & Sig. (2-tailed) \\
\hline Pair 1 & Genuineness (pre-post) & .12628 & $.030^{* *}$ \\
Pair 2 & Competence (pre-post) & .07299 & .238 \\
Pair 3 & Excitement (pre-post) & .12591 & $.090^{*}$ \\
Pair 4 & Sociability (pre-post) & .09307 & .255 \\
\hline
\end{tabular}

Note. **: 0.05 Significant;*: 0.10 Significant.

In this low Genuineness score means higher Genuineness as the scale varies from 1-5 and 5 being least Genuine. The same applies to all the other image constructs.

Table 10. Paired sample T-Test for Kajol for only male respondents

\begin{tabular}{llll}
\hline Pair & Variable & Mean Difference & Sig. (2-tailed) \\
\hline Pair 1 & Genuineness (pre-post) & -.02400 & .770 \\
Pair 2 & Competence (pre-post) & -.11180 & .328 \\
Pair 3 & Excitement (pre-post) & .20000 & $.086^{*}$ \\
Pair 4 & Sociability (pre-post) & .07500 & .567 \\
\hline
\end{tabular}

Note.*: 0.10 Significant.

In this low Genuineness score means higher Genuineness as the scale varies from 1-5 and 5 being least Genuine. The same applies to all the other image constructs.

Table 11. Paired sample T-Test for Saniamirza for female respondents

\begin{tabular}{llll}
\hline Pair & Variable & Mean Difference & Sig. (2-tailed) \\
\hline Pair 1 & Genuineness (pre-post) & -.03723 & .600 \\
Pair 2 & Competence (pre-post) & -.14051 & $.088^{*}$ \\
Pair 3 & Excitement (pre-post) & .12781 & .115 \\
Pair 4 & Sociability (pre-post) & .01883 & .837 \\
\hline
\end{tabular}

Note.*: 0.10 Significant. 
In this low Genuineness score means higher Genuineness as the scale varies from 1-5 and 5 being least Genuine. The same applies to all the other image constructs.

Table 12. Paired sample T-Test for Saniamirza for male respondents

\begin{tabular}{llll}
\hline Pair & Variable & Mean Difference & Sig. (2-tailed) \\
\hline Pair 1 & Genuineness (pre-post) & .00000 & 1.000 \\
Pair 2 & Competence (pre-post) & .17500 & $.085^{*}$ \\
Pair 3 & Excitement (pre-post) & -.11000 & .238 \\
Pair 4 & Sociability (pre-post) & .13000 & .291 \\
\hline
\end{tabular}

Note.*: 0.10 Significant.

In this low Genuineness score means higher Genuineness as the scale varies from 1-5 and 5 being least Genuine. The same applies to all the other image constructs.

\subsection{Effect of Respondent's Gender on the Shift in the Celebrity's Image in Case of Incongruent Endorsements}

In order to test the influence of respondent's gender in the shift in celebrity's image in case of incongruent endorsements, t-test is carried out. The analysis of interaction of respondents' gender with celebrity gender showed significant results. Female respondents had rated Shahrukh Khan positively on two constructs namely Genuineness (Sig. 2-tailed: 0.002) and Excitement (Sig. 2-tailed: 0.044) and male respondents had rated him negatively on Competence (Sig. 2-tailed: 0.043). Table 5 shows the impact of female respondents and Table 6 shows the impact of male respondents on Shahrukh Khan. For Sachin Tendulkar, female respondents rated him positively on Excitement (Sig. 2-tailed: 0.016) and there was no significant change in the male respondents rating. Table 7 shows the impact of female subjects and Table 8 shows the impact of male subjects on Sachin Tendulkar. For Kajol, interaction of respondents' gender with celebrity gender showed a positive shift in the image. Both males and female respondents rated her positively after seeing the incongruent ads. Female respondents rated her positively on Genuineness (Sig. 2-tailed: 0.030) and Excitement (Sig. 2-tailed: 0.090) and male respondents rated her positively on Excitement (Sig. 2-tailed: 0.086). Table 9 shows the impact of female subjects and Table 10 shows the impact of male subjects on Kajol. For SaniaMirza, analysis of interaction of respondents' gender with celebrity gender showed significant results; female respondents had decreased her rating on Competence (Sig. 2-tailed: 0.088 ) while male respondents rated her positively on Competence (Sig. 2-tailed: 0.085 ). Table 11 shows the impact of female subjects and Table 12 shows the impact of male subjects on Sania Mirza's image.

Findings partly supported the Hypothesis $\mathrm{H}_{2}$. When consumers really like and adore a celebrity; Sachin Tendulkar and Kajol in this case, the gender does not have any impact in the evaluation of the image, but when the respondents are ambivalent towards the celebrity the gender impacts the celebrity image.

\section{Discussion}

The results showed different celebrities were affected differently by incongruent endorsements. It was found, shift in the celebrity image was significant for some of the sub-constructs and that too positively. This was quite in contrast to the findings reported in the literature, where (Kiesler, 1988) a study done to find out the influence a particular product may have on consumers' perceptions of the spokesperson endorsing that product and had measured the spokesperson on 8 personality traits. The findings indicated that there is no or little evidence for the influence of any of the variables on consumers' perception of spokesperson for different products. This study founds support in (Till \& Shimp, 1998) work where they observe negative information about the celebrity resulted in decline of the attitude towards the celebrity only in case of fictitious celebrity and not real celebrity endorser. (Till \& Shimp, 1998) explains this by mentioning that possibly subjects had richer association set for the real celebrity which may have diluted the impact of negative information.

Shahrukh Khan was rated negatively on Competence and Sania Mirza was rated negatively on Genuineness and Competence but none of them were found to be significant. The other two celebrities were rated positively on all constructs. It was also interesting to observe that respondents positively rated (significant) on two constructs only, Genuineness and Excitement. Additionally it was noted that the behavior of male and female subjects towards Sachin Tendulkar and Kajol did not vary by the respondent's gender but varied for Shahrukh Khan and Kajol. Sociability as an image construct was not found to be significant either positively or negatively. 
Sachin Tendulkar is considered a national hero for his contribution to cricket and hence he is loved by youth. Similarly Kajol is considered to represent an ideal Indian woman and is liked by both men and women alike. Both these celebrities were rated very highly on Genuineness compared to other two (Shahrukh Khan \& Sania Mirza) during the pre-test. These two celebrities were not at all affected by the incongruent endorsements; instead they were rated more positively after the respondents saw the incongruent ads. Both the male and female subjects positively increased their rating significantly; on Genuineness and Excitement for Kajol and only Excitement for Sachin Tendulkar.

In the case of the other two celebrities, Shahrukh Khan and Sania Mirza their rating went down. This was more prominent in case of Sania Mirza as her rating went down on both Genuineness and Competence after the respondents were exposed to incongruent endorsements, though not significantly. Sania Mirza is an ace Indian tennis player and holds the record for being the highest ranked Indian player for over a decade in between 2003-2013. She was loved by youth, but her marriage to a Pakistani cricketer in 2010 made her unpopular among the majority of Indians. The effect of respondent's gender was quite prominent in her case. Males rated her positively on Competence significantly while female respondents decreased it. Shahrukh Khan is considered a very versatile actor and respondents. Though he is a popular celebrity yet people have mixed opinion about him. Females like him more than males and this was found in the study as well. When checked for impact of incongruent product endorsement on his image, rating was negative only on Competence and that too was not significant. But a deeper analysis of the effect of respondent's gender revealed that male respondents evaluated him significantly negative on Competence while female respondents evaluated him significantly positive on Genuineness and Excitement.

\section{Conclusion and Implications}

This study has significant implications for academicians as well as marketers. This is the first study that has attempted to study the impact of daily use products, which themselves do not have any negative image connotation, but do not match with the image of the celebrity and tried to find their impact on the celebrity who endorses them. We checked for incongruence of the product categories with the celebrity's image for regular products that may not appear damaging initially but may bring down the celebrity image. Additionally this is the first study to report that different celebrities are affected differently when they do incongruent endorsements. The study investigates the above in an emerging market and brings in the importance of para-social relationship (Alperstein, 1991), where people feel as if they know the celebrity and also idolize them.

\subsection{Implications for Academicians}

In this study two celebrities (Sachin Tendulkar \& Kajol) were rated higher than the other two (Shahrukh Khan \& Sania Mirza) in the pre-test and were rated even higher after viewing incongruent advertisements. The possible reason for this could be that since the subjects felt highly connected with the celebrity the one instance of incongruent endorsement did not affect their belief about the celebrity, and thus they stuck to their original belief. The respondents' already had a positive opinion of these celebrities and when they were exposed to the endorsements by these celebrities, they chose to ignore the incongruent endorsement and instead focused more on the congruent advertisement. The reverse of this was exhibited in the case of Sania Mirza whose already low rating fell even more after the respondents' were shown her endorsements. The behavior of the respondents' can be explained with the help of cognitive dissonance theory. The theory of cognitive dissonance explains this behavior by stating that individuals, when faced with a dilemma, have a motivational drive to decrease dissonance. They do this by altering cognitions, adding new ones to create a consistent belief system, or alternatively by reducing the importance of any one of the dissonant elements. In the above study, respondents were faced with dilemma twice, once when they were exposed to incongruent endorsements by their favorite celebrities and then again when they were shown incongruent endorsements by the celebrity they did not like much. They reduced this dissonance by rating their favorite celebrities more positively on all image dimensions while rating the celebrity they did not like, much negatively. This was done to stay consistent with the belief system they had built about these celebrities over the years.

The results of the study imply that not all celebrities who do incongruent endorsements get affected negatively. Some celebrities get affected positively and some negatively. No study has found that a case of mismatch can lead to positive image for some celebrities and negative for some other celebrities. In cases where the celebrity is getting affected negatively by doing an incongruent endorsement both the brand and the celebrity end up losing. What is interesting to note is that consumers create para-social relations (Horton \& Wohl, 1956) with the celebrities based on their actions in the real world. Consumers either fall in love with these celebrities or dislike them. Generally these perceptions are built over time through media exposure. A well-liked celebrity can get 
away with incongruent endorsements while a celebrity whose public image is not very good, will be evaluated very negatively on account of the incongruent endorsement. This phenomenon is experienced in real life too, where people tend to defend the wrongful actions of their loved ones, while heavily criticize those they do not like for the same action.

Results further imply that customer's gender does impact the relationship and if the celebrity is not well liked then the impact will be prominent. Female consumers will be harsher in evaluating the female celebrity and vice-versa. Though this may not hurt the image of the celebrity directly but if the celebrity is endorsing congruent (for instance female celebrity endorses cosmetics) and incongruent products both, both the endorsements might be rejected by the same gender consumers.

\subsection{Implications for the Practitioners}

Understanding the shift in celebrity image due to their endorsements is very important for practitioners. This study will help them realize that celebrities' images may get harmed over time due to the kind of endorsements they do and also help them to keep a tab on such endorsements. Celebrity management companies like Percept India, IMG Worldwide and other event management companies have lifelong contracts with celebrities and manage celebrities' portfolios. It is very important for these companies that celebrities' image does not get tarnished. A large amount of money and reputation of the marketer's brand is at stake. Hence celebrities and marketers should be aware of the public perception regarding the celebrity and choose endorsements accordingly. Mostly celebrity selection by the advertising agency and the client for the endorsement is a gut based decision rather than science. "Respondents mostly argued that a celebrity must be right for the advertising idea though it is ambiguous as to how one decides whether the celebrity is right" (Erdogan \& Baker, 2000a, p. 7). This study will help marketers assess the current image of the celebrity and take adequate precautions in case the celebrity is doing parallel endorsements which may be incongruent to the celebrity's image as it may affect the marketer's brand. This is the first study which distinguishes the consumers' response towards incongruent endorsements between a well-liked celebrity and someone who is not liked too much.

\section{Limitations and Future Study}

The hypotheses in this study were tested using movie and sport celebrities and future research should try to extend the generalizability of the study on a variety of celebrities such a writers, celebrity chefs, musicians, dancers, etc., having different careers with diverse images. The sample for this study was urban college going young adults and future studies can be conducted across the other socio-economic segments to enhance the generalization of the hypotheses. Since this study was conducted in emerging market, future research could assess if the results reported by this study are similar to consumers from different cultural origins or not. Effect of exposure to the same incongruent advertisement over a long period of time can have different results from seeing the advertisement only once (Lane, 2000). Additionally exposure to more than one incongruent advertisement for a longer duration may also have different outcomes. An extended longitudinal study can be conducted to check if the increase in frequency and quantity of incongruent advertisements affect the celebrity image in the long run.

\section{References}

Alperstein, N. M. (1991). Imaginary Social Relationships with Celebrities Appearing in Television Commercials. Journal of Broadcasting \& Electronic Media, 35(1), 43.http://doi.dx.org/10.1080/08838159109364101

Baker, M. J., \& Churchill Jr., G. A. (1977). The Impact of Physically Attractive Models on Advertising Evaluations. Journal of Marketing Research (JMR), 14(4), 538-555. http://dx.doi.org/10.2307/3151194

Batra, R., \& Homer, P. M. (2004). The Situtational Impact of Brand Image Beliefs. Journal of Consumer Psychology, 14(3), 318-330. http://dx.doi.org/10.1207/s15327663jcp1403_12

Berlo, D. K., Lemert, J. B., \& Mertz, R. J. (1969). Dimensions for Evaluating the Acceptability of Message Sources. The Public Opinion Quarterly, 33(4), 563-576. http://dx.doi.org/10.1086/267745

Biswas, S., Hussain, M., \& O'Donnell, K. (2009). Celebrity Endorsements in Advertisements and Consumer Perceptions: A Cross-Cultural Study. Journal of Global Marketing, 22(2), 121-137. http://doi.dx.org/10.1080/08911760902765940

Bower, A. B. (2001). Highly Attractive Models in Advertising and the Women Who Loathe Them: The Implications of Negative Affect for Spokesperson Effectiveness. Journal of Advertising, 30(3), 51-63. http://dx.doi.org/10.1080/00913367.2001.10673645 
Choi, S. M. (2002). Attributional approach to understanding celebrity/product congruence effects: Role of perceived expertise (Doctoral dissertation, Department of Advertising, Michigan State University).

Choi, S. M., \& Rifon, N. J. (2007). Who Is the Celebrity in Advertising? Understanding Dimensions of Celebrity Images. The Journal of Popular Culture, 40(2), 304-324. http://dx.doi.org/10.1111/j.1540-5931.2007.00380.x

Clinton, A., Gary, H., \& David, S. (2008). Exploring the Relationship between Celebrity Endorser Effects and Advertising Effectiveness: A Quantitative Synthesis of Effect Size. International Journal of Advertising, 27(2), 209-234. Retrieved from http://www.hull.aug.edu/hcbWeb/media/research/Amos-Holmes-Strutton-IJA-2008.pdf

Edwards, S. M., \& La Ferle, C. (2009). Does Gender Impact the Perception of Negative Information Related to Celebrity Endorsers? Journal of Promotion Management, 15(1/2), 22-35. http://dx.doi.org/10.1080/10496490902837940

Erdogan, B., \& Baker, M. (2000). Celebrity endorsement: Advertising agency manager's perspective. The Cyber Journal of Sport Marketing, 13(December), 1-15. Retrieved from http://fulltext.ausport.gov.au/fulltext/1999/cjsm/v3n3/erdogan\&baker33.htm

Fleck, N. D., \& Quester, P. (2007). Birds of a Feather Flock Together...definition, Role and Measure of Congruence: An Application to Sponsorship. Psychology \& Marketing, 24(11), 975-1000. http://doi.dx.org/10.1002/mar.20192

Folkes, V. S. (1984). Consumer Reactions to Product Failure: An Attributional Approach. Journal of Consumer Research, 10(4), 398-409. http://dx.doi.org/10.1086/208978

Frieden, J. B. (1984). Advertising Spokesperson Effects: An Examination of Endorser Type and Gender on Two Audiences. Journal of Advertising Research, 24(5), 33-41. Retrieved from http://www.citeulike.org/user/gyluckygo/article/8309583

Friedman, H. H., \& Friedman, L. (1979). Endorser Effectiveness by Product Type. Journal of Advertising Research, 19(5), 63-71. $\quad$ Retrieved from http://legacy.library.ucsf.edu/documentStore/c/t/q/ctq10j00/Sctq10j00.pdf

Heckler, S. E., \& Childers, T. L. (1992). The Role of Expectancy and Relevancy in Memory for Verbal and Visual Information: What Is Incongruency? Journal of Consumer Research, 18(4), 475-492. http://dx.doi.org/10.1086/209275

Horton, D., \& Wohl, R. R. (1956). Mass Communication and Para-social Interaction. Psychiatry, 19, 215-229. Retrieved from http://www.aber.ac.uk/media/Documents/short/horton_and_wohl_1956.html

Jain, V., Sudha, M., \& Daswani, A. (2009). Customer Perception About Celebrity Endorsement in Television Advertising for Retail Brands. IUP Journal of Brand Management, 6(3/4), 7-25. Retrieved from http://papers.ssrn.com/sol3/papers.cfm?abstract_id=1531470

Kamins, M. A. (1990). An Investigation Into the "Match-Up" Hypothesis in Celebrity Celebrity Advertising: When Beauty May be Only Skin Deep. Journal of Advertising, 19(1), 4-13.http://doi.dx.org/10.1080/00913367.1990.10673175

Kamins, M. A., \& Gupta, K. (1994). Congruence between Spokesperson and Product Type: A Matchup $\begin{array}{lllll}\text { Hypothesis Psychology } \quad \text { Perspective. } & \text { Marketing, }\end{array}$ 569-586.http://dx.doi.org/10.1002/mar.4220110605

Kanungo, R. N., \& Pang, S. (1973). Effects of Human Models on Perceived Product Quality. Journal of Applied Psychology, 57(2), 172-178. http://dx.doi.org/10.1037/h0037042

Keller, K. L. (1993). Conceptualizing, Measuring, and Managing Customer-Based Brand Equity. Journal of Marketing, 57(1), 1-22. http://dx.doi.org/10.2307/1252054

Keller, K. L., Heckler, S. E., \& Houston, M. J. (1998). The effects of brand name suggestiveness on advertising recall. The Journal of Marketing, 48-57. http://dx.doi.org/10.2307/1251802

Kennedy, S. H. (1977). Nurturing Corporate Images. European Journal of Marketing, 11(3), 119-164. http://dx.doi.org/10.1108/EUM0000000005007 
Kiesler, T. (1988). The Flip Side of the Persuasion Equation: Does a Product Influence a Spokesperson's Public Image? Advances in Consumer Research, 15(1), 62-68. Retrieved from http://www.acrwebsite.org/search/view-conference-proceedings.aspx?Id=6795

Klaus, N., \& Bailey, A. A. (2008). Celebrity Endorsements: An Examination of Gender and Consumers' Attitudes. American Journal of Business, 23(2), 53-61. http://doi.dx.org/10.1108/19355181200800010

Knittel, C., \& Stango, V. (2010). Shareholder Value Distruction Following the Tiger Woods Scandal (pp. 1-14). University of California. Retrieved from http://scholar.google.com/scholar?start=0\&q=tiger+woods+losing+celebrity+endorsement $+\&$ hl=en\&as_sdt $=0,5$

Lane, V. R. (2000). The Impact of Ad Repetition and Ad Content on Consumer Perceptions of Incongruent Extensions. Journal of Marketing, 64(2), 80-91. http://dx.doi.org/10.1509/jmkg.64.2.80.17996

Langmeyer, L. (1991). Exploring Gender Influences of Meanings In Celebrity Endorsers. Gender and Consumer Behavior, 1, 158-172.

Langmeyer, L., \& Walker, M. (1991). A First Step to Identify the Meaning in Celebrity Endorsers. Advances in Consumer Research, 18(1), 364-371. Retrieved from http://www.acrwebsite.org/search/view-conference-proceedings.aspx?Id=7186

Lynch, J., \& Schuler, D. (1994). The Matchup Effect of Spokesperson and Product Congruency: A Schema Theory Interpretation. Psychology \& Marketing, 11(5), 417-445. http://dx.doi.org/10.1002/mar.4220110502

Malhotra, M. K., \& Grover, V. (1998). An Assessment of Survey Research in Pom: From Constructs to Theory. Journal of Operations Management, 16(4), 407-425. http://dx.doi.org/10.1016/S0272-6963(98)00021-7

Malhotra, N. K. (2004). Marketing Research: An Applied Orientation (4th ed.). New Delhi: Pearson Education, Inc.

Meyers-Levy, J., Louie, T. A., \& Curren, M. T. (1994). How Does the Congruity of Brand Names Affect Evaluations of Brand Name Extensions? Journal of Applied Psychology, 79(1), 46-53. http://dx.doi.org/10.1037/0021-9010.79.1.46

Miciak, A. R., \& Shanklin, W. L. (1994). Choosing Celebrity Endorsers. Marketing Management, 3(3), 50-59. Retrieved from https://archive.ama.org/archive/ResourceLibrary/MarketingManagement/Pages/1994/3/3/9412304020.aspx

Misra, S., \& Beatty, S. E. (1990). Celebrity Spokesperson and Brand Congruence: An Assessment of Recall and Affect. Journal of Business Research, 21(2), 159-171. http://doi.dx.org/10.1016/0148-2963(90)90050-N

Narasimhan, R., \& Jayaram, J. (1998). Causal Linkages in Supply Chain Management: An Exploratory Study of North American Manufacturing Firms. Decision Sciences, 29(3), 579-605. http://dx.doi.org/10.1111/j.1540-5915.1998.tb01355.x

Ohanian, R. (1991). The Impact of Celebrity Spokespersons' Perceived Image on Consumers' Intention to Purchase. Journal of Advertising Research, 31(1), 46-54. http://psycnet.apa.org/psycinfo/1991-26094-001

Premeaux, S. R. (2005). The Attitudes of Middle Class Male and Female Consumers Regarding the Effectiveness of Celebrity Endorsers. Journal of Promotion Management, 11(4), 33-48. http://dx.doi.org/10.1300/J057v11n04_04

Roy, S., Gammoh, B. S., \& Koh, A. C. (2012). Predicting the Effectiveness of Celebrity Endorsements Using the Balance Theory. Journal of Customer Behaviour, 11(1), 33-52. http://dx.doi.org/10.1362/147539212X13286273975238

Salovey, P., \& Rodin, J. (1984). Some Antecedents and Consequences of Social-Comparison Jealousy. Journal of Personality and Social Psychology, 47(4), 780-792. http://dx.doi.org/10.1037//0022-3514.47.4.780

Seno, D., \& Lukas, B. A. (2007). The Equity Effect of Product Endorsement by Celebrities. European Journal of Marketing, 4l(1/2), 121-134. http://doi.dx.org/10.1108/03090560710718148

Sparkman Jr., R. M. (1982). The Discounting Principle in the Perception of Advertising. Advances in Consumer Research, 9(1), 277-280. 
Speck, P. S., Schumann, D. W., \& Thompson, C. (1988). Celebrity Endorsements-Scripts, Schema and Roles: Theoretical Framework and Preliminary Tests. Advances in Consumer Research, 15(1), 69-76. Retrieved from http://www.acrwebsite.org/search/view-conference-proceedings.aspx?Id=6799

Till, B. D. (2001). Managing Athlete Endorser Image: The Effect of Endorsed Product. Sport Marketing Quarterly, 10(1), 35-42. Retrieved from http://elibrary.ru/item.asp?id=4054646

Till, B. D., \& Busler, M. (2000). The Match-Up Hypothesis: Physical Attractiveness, Expertise, and the Role of Fit on Brand Attitude, Purchase Intent and Brand Beliefs. Journal of Advertising, 29(3), 1-13. http://dx.doi.org/10.1080/00913367.2000.10673613

Till, B. D., \& Shimp, T. A. (1998). Endorsers in Advertising: the Case of Negative Celebrity Information. Journal of Advertising, 27(1), 67-82. http://dx.doi.org/10.1080/00913367.1998.10673543

Walker, M., Langmeyer, L., \& Langmeyer, D. (1992). Commentary-Celebrity Endorsers: Do You Get What You Pay For? The Journal of Services Marketing, 6(4), 35-42. http://dx.doi.org/10.1108/EUM0000000002531

Walker, M., Langmeyer, L., \& Langmeyer, D. (1993). Commentary: Celebrity Endorsers-Do You Get What You Pay For? The Journal of Product and Brand Management, 2(3), 36-43. http://doi.dx.org/10.1108/EUM0000000002978

\section{Copyrights}

Copyright for this article is retained by the author(s), with first publication rights granted to the journal.

This is an open-access article distributed under the terms and conditions of the Creative Commons Attribution license (http://creativecommons.org/licenses/by/3.0/). 